\title{
FINANCIALISATION AND THE COUPON POOL
}

\section{GESTÃO \\ $\&$ \\ PRODUÇÃO}

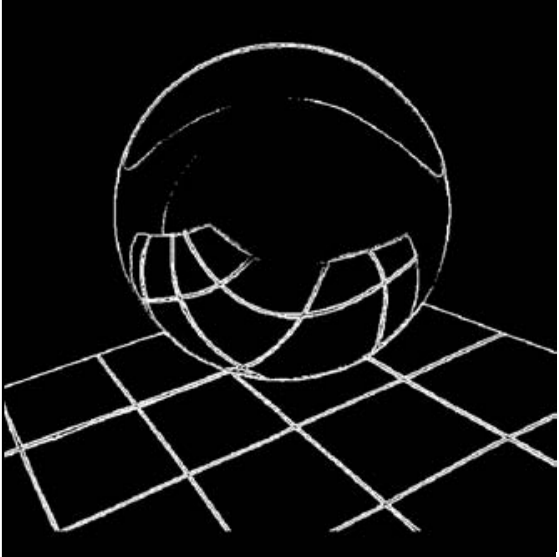

v.8, n.3, p.271-288, dez. 2001
Julie Froud

Colin Haslam

Sukhdev Johal

Karel Williams

School of Accounting and Finance

Crawford House, University of Manchester

Manchester M13 9PL

E-mail: karel.williams@man.ac.uk

\section{Abstract}

By the late 1990s, shareholder value was the explicit, new priority for the old corporations in the US and UK where the stock market had gained an unprecedented influence on the behaviour of giant corporations. The business press obsessively discussed which managements were, and were not, delivering value and all the major US consulting firms had moved into selling value metrics and implementation packages promising to solve this question. Over this decade, share prices rose unsteadily in a long bull market which ended in the tech stock crash of Spring 2000 which, one year later, had turned into a bear market in a slowing US economy. All this poses new questions about what's at stake in the capital market's pressure on corporations for increased returns; and what's behind higher share prices and their collapse? The intellectual responses widened the debate but has led to increasing conceptual confusion: the journalistic term "shareholder value" has passed into academic usage; while neologisms such as financialisation are used differently by various authors. Against this background, our paper aims to discuss the existing terms and main definitions and to argue for a redefinition of the problem around a new generic concept of coupon pool capitalism. After this, the paper presents a brief empirical analysis of the dynamics of the coupon pool in the USA and UK. This analysis represents part of our answer to the question of what's new and different about the current forms of capitalism.

Key words: kinds of Capitalism, corporate governance, "finacialization", kinds of wealth, kinds of income, shareholder revolution. 


\section{Introduction}

R ecent developments have highlighted the Rcapital market's role in present day capitalism. By the late 1990s, shareholder value was the explicit, new priority for the old corporations in the US and UK where the stock market had gained an unprecedented influence on the behaviour of giant corporations. The business press obsessively discussed which managements were, and were not, delivering value and all the major US consulting firms had moved into selling value metrics and implementation packages of the kind pioneered by Stern Stewart and LEK/Alcar (FROUD, 2000a). Over this decade, share prices rose unsteadily in a long bull market which ended in the tech stock crash of Spring 2000 which, one year later, had turned into a bear market in a slowing US economy. All this poses new questions about what's at stake in the capital market's pressure on corporations for increased returns; and what's behind higher share prices and their collapse?

The intellectual responses so far include a schism in corporate finance where believers in efficient markets have been challenged by behavioural finance academics like SHILLER (2000) who emphasises market psychology. Problems of corporate governance have been increasingly discussed by academics and agencies like OECD with governance itself variously defined as solving an agency problem about management action for shareholder interests or creating the conditions for corporate innovation (O'SULLIVAN, 2000). A broader debate amongst political economists, was inaugurated by a special issue of Economy and Society (see WILLIAMS, 2000) which included contributions by the regulationists Boyer and Aglietta introducing the concept of financialisation and the possibility of a "wealth based growth regime".

Widening debate has led to increasing conceptual confusion: the journalistic term "shareholder value" has passed into academic usage; while neologisms such as financialisation are used differently by various authors. Against this background, our paper has a double aim and is organised in a relatively straightforward way. The first half aims to provide some exposition and clarification by discussing the strength and weaknesses, power and limits, of the existing terms and main definitions before going on to argue for a redefinition of the problem around a new generic concept of coupon pool capitalism. The second half then builds on this foundation and presents a brief empirical analysis of the dynamics of the coupon pool in the USA and UK. This analysis represents part of our answer to the question of what's new and different about the current forms of capitalism.

\section{Definitions and Cases: from Shareholder Value to Coupon Pool Capitalism}

$\mathrm{T}$ axonomy is not an end in itself but classifications do have some practical value. Classification reduces inexactitude and misunderstanding by encouraging controlled and precise definitions of the kind that have too often been missing in, for example, debates about globalisation. Users with strong discursive affiliations can then situate their preferred definition in a complex field; those without such affiliations can choose an appropriate definition and understand its limits. Finally, on this basis, it is possible to delimit a defensible intellectual object; by explaining what financialisation is (and is not) and by introducing a new concept of coupon pool capitalism which addresses dynamics in a new way. The central exhibit in this section is Table 1 which classifies four existing concepts of shareholder value and financialisation according to the field of the visible and relates them to our new concept of coupon pool capitalism.

Shareholder value is the (untheorised) low definition term used by consultants, media and some managements with a breezy confidence which implies that everybody knows what it means. In a common sense way it denotes the capital market's pressure on corporations for increased return on capital employed and rising 
Table 1 - Concepts of Shareholder Value and Financialisation

\begin{tabular}{|c|c|c|c|c|}
\hline Concept & Promoters & Field of the visible & Power & Limits \\
\hline Shareholder Value & $\begin{array}{l}\text { a) Consultants } \\
\text { eg Stern Stewart } \\
\text { b) Media } \\
\text { eg Lex, FT }\end{array}$ & $\begin{array}{l}\text { Untheorised, } \\
\text { Management (for) } \\
\text { shareholders }\end{array}$ & $\begin{array}{l}\text { Pop. management, } \\
\text { (like lean production) } \\
\text { object of emulation }\end{array}$ & $\begin{array}{l}\text { Decontextualises, } \\
\text { abolishes constraint, no } \\
\text { object of analysis }\end{array}$ \\
\hline $\begin{array}{l}\text { Corporate } \\
\text { Governance }\end{array}$ & $\begin{array}{l}\text { a) Narrow: agency } \\
\text { theory } \\
\text { b) Broad: } \\
\text { eg O'Sullivan }\end{array}$ & $\begin{array}{l}\text { a) Private (investor) } \\
\text { benefit } \\
\text { b) socio-economic } \\
\text { purpose eg } \\
\text { innovation }\end{array}$ & $\begin{array}{l}\text { Focus on actors, } \\
\text { resource allocation } \& \\
\text { the corporation }\end{array}$ & $\begin{array}{l}\text { Simple identities, } \\
\text { mechanical cause-effect } \\
\text { relations }\end{array}$ \\
\hline $\begin{array}{l}\text { Financialisation(a) } \\
\text { (National) Forms of } \\
\text { Capitalism }\end{array}$ & $\begin{array}{l}\text { Institutional } \\
\text { sociologists } \\
\text { eg Dore }\end{array}$ & $\begin{array}{l}\text { Corporations, } \\
\text { financial institutions } \\
\text { (organised labour, } \\
\text { the state) }\end{array}$ & $\begin{array}{l}\text { Registers institutional } \\
\text { differences, associates } \\
\text { them with behaviour } \\
\text { and performance }\end{array}$ & $\begin{array}{l}\text { Describes forms, } \\
\text { rationalizes performance, } \\
\text { corporate part represents } \\
\text { whole economy }\end{array}$ \\
\hline $\begin{array}{l}\text { Financialisation(b) } \\
\text { Macro and } \\
\text { Monetary Flows }\end{array}$ & $\begin{array}{l}\text { a) Social accountants } \\
\text { eg Froud et al. } \\
\text { b) Regulationists } \\
\text { eg Boyer }\end{array}$ & $\begin{array}{l}\text { a) Adds households } \\
\text { b) \& growth } \\
\text { regimes }\end{array}$ & $\begin{array}{l}\text { Macro linkages: } \\
\text { a) flows into stock } \\
\text { market } \\
\text { b) problems of asset } \\
\text { prices etc }\end{array}$ & $\begin{array}{l}\text { Simplified cases, retains } \\
\text { mechanics }\end{array}$ \\
\hline $\begin{array}{l}\text { Coupon Pool } \\
\text { Capitalism }\end{array}$ & & $\begin{array}{l}\text { Generic type of } \\
\text { capitalism }\end{array}$ & $\begin{array}{l}\text { Dynamics: } \\
\text { a) contradiction and } \\
\text { incoherence } \\
\text { b) mutability of } \\
\text { behaviour and } \\
\text { performance }\end{array}$ & $\begin{array}{l}\text { Whatever next? } \\
\text { indeterminacy of } \\
\text { identities, relations and } \\
\text { outcomes }\end{array}$ \\
\hline
\end{tabular}

share prices and, in response, what corporate management does for shareholders. At the same time, shareholder value is a slippery, dangerous concept because it is a catch all market slogan and blurred management agenda. Shareholder value signals a new emphasis on financial results at company level but does so in a way which creates problems familiar from earlier popular management concepts. Like lean production a decade previously, shareholder value is an object of emulation because this is what every management must buy into; it is not an object of analysis because it means what users want it to mean and encourages opportunism and hypocrisy. Again, like previous popular management concepts, shareholder value has a strong religious element when the vignettes in consultancy texts show how purposive management is gratifyingly rewarded with improved financial results for shareholders. This illusion about cause and effect is obtained in the classic way by decontextualising management effort and ignoring the problem that most firms cannot easily deliver because of structural constraints related to activity and product market (see FROUD, 2000a).

Corporate governance adds a theorisation of whether and how management acts for shareholders and with what consequences. Governance theory comes in several different forms and it is important to distinguish between narrow agency theorists, concerned with whether management is acting for private (investor) benefits, and broad theorists like O'Sullivan and Lazonick who credit corporate management with a socio-economic purpose of innovation. All the variants present a kind of theorisation which 
both brings intellectual prestige and simplifies identities and relations in a way that increases popular accessibility: the world of governance is an old fashioned Hollywood western with a clear distinction between good guys and bad guys and a simple plot about the consequences of identity. The power of this approach rests on its focus on a few actors with definite motives, acting around resource allocation and mis-allocation inside the corporation. The limit is that it sets up a mechanical universe where following or breaking the rules of good governance has predictable results and generally suppresses meso and macro analysis by constructing the economy as a bundle of corporations and the corporation as a bundle of investment projects. This narrow focus helps to explain why better corporate governance is so attractive to organisations like the OECD and World Bank and why the rest of us should be cautious, at least unless corporate governance is defined more broadly to include sectoral and chain issues about the exercise of power at meso level.

Through discussion of (national) forms of capitalism, institutional sociology broadens the field of the visible to consider not only corporations and financial institutions, but also the role of organised labour and the state, within specific national configurations. Here we have the familiar contrast between stock market and bank finance in Anglo American and Rhenish capitalisms whose forms of calculation are productionist or financialised and short term. DORE (2000) inserts financialisation into this pre-existing problematic as a mutation in the national form of Anglo American capitalism under pressure from the stock market and as a contagion spreading into other national forms whose institutions have a limited capacity to frustrate change. The power of this approach arises from the way in which it registers national differences and credits specific configurations with definite behaviour and performance characteristics. The limit is that it describes forms rather than explains performance. Indeed, the standard line about behaviour and performance correlates has to be reworked as every new phase of capitalist development turns up unexpected anomalies such as the combination of Japanese economic failure and US success in the 1990s. More fundamentally, the part represents the whole and the corporate sector is represented as the economy, although in the UK and the USA the corporate sector represents only around half of national income.

Finally, in analysing existing definitions, we should distinguish the meaning of financialisation when that term is used by British social accountants (FROUD, 2001) and French regulationists (BOYER, 2000) who are both, in different ways, concerned with a macro mechanics of circuits, flows and sectors with issues of linkage, leverage and magnitude. Both groups use financialisation to denote the consequences and concomitants of widespread share ownership in a frame where macro flows and monetary forms are crucial. The power of this approach comes from the way in which it extends the field of the visible in two ways. First, both groups identify the household as a key institution in a financialised economy, where savings and investment circuits divert middle class long term savings and expectations for retirement onto the stock market and where the household buffers the consequences for individuals who have not made the necessary savings. Second, the regulationists raise questions about growth regimes and macro economic trajectory which highlight new problems about asset price inflation and the importance of monetary policy in a post Keynesian world. This approach powerfully identifies key linkages and generates paradoxes, such as the possible benefits of wage reductions in BOYER's (2000) model. But this approach models simplified cases as when Boyer, for example, excludes commodity trade and capital flows. More fundamentally, the approach also raises issues about the limits of mechanics if, as these authors conclude, financialisation intensifies capitalist contradiction and takes us away from coherence and stability.

The analysis of existing usage suggests several conclusions which are relevant to those trying to understand current developments: 
1) The trickiest concept is the one that everybody uses. Shareholder value is an empty rhetoric which users inject with a variety of opportunistic meanings to explain or criticise action and performance. In our view, this is not an object of analysis but an object for analysis in studies of adoption and adaption as shareholder value is socially redefined for new times and places when it migrates from its origins in the USA in the 90s.

2) The other concepts find contestable objects at different levels of the economy and users should remember these differences of focus ensure each concept is partial and create puzzles about whether and how it all fits together. Governance entirely abstracts from macro issues; while the macro logics of financialisation cannot determine management calculation and action at firm or factory level.

3) For all their differences, the existing concepts generally share a mechanical view of the world. In the more descriptive concepts, outcomes are the consequence of stable relations and identities. In discussing financialisation, the regulationists admit incoherent outcomes and the social accountants emphasise contradictory processes, but neither so far offers concepts which emphasise open dynamics rather than closed mechanics.

The concept of coupon pool capitalism is designed to redress this absence and open up dynamic issues about changes in behaviour. It does this by breaking with the specific form assumptions shared by sociologists and regulationists when they write of national capitalisms or specific growth regimes. Instead, we hypothesis two generic types of capitalism: coupon pool capitalism is a new generic type where the pool of new and issued coupons becomes a regulator of firm and household behaviour and a regulator of macro economic trajectory; by way of contrast, in an earlier, productionist type of capitalism, the capital market is an unproblematic intermediary between saving households and productionist firms, or between some firms such as banks or network leaders who own stakes in other firms. The functions of the capital market are many and various in productionist and coupon pool systems. In developing countries, such as Japan after 1945, household savings may be diverted into productive investment. More usually, in advanced capitalist countries the corporate sector is self financing, so the main emphasis is on the secondary market which resolves the conflict between the immobility of productive investment and the time preferences of many saving households. The secondary market can do this either by constituting some firms (like banks) as patient investors or by creating a liquid market where household investors (or funds pooling household savings) can freely buy and sell claims on corporate earnings. These claims are generically coupons and could take the form of bonds with fixed entitlements, ordinary shares or some other kind of instrument; bonds can be issued by for profit corporations, the central or local state or any other entity with a legal claim on an income stream from assets.

Coupon pool capitalism is constituted when, under specific conditions, the capital market moves from intermediation to regulation of firm and household behaviour. For households, the basic condition is the diversion of a substantial part of long term savings (or provision for old age) into securities which creates a volume flow onto the secondary market. The coupons can be held directly by households or indirectly by pension funds and insurance companies pooling household savings. The conditions necessary for regulation of firm behaviour have been incisively discussed by MORGAN \& TAKAHASHI (2001) and his conditions are summarised below, with less emphasis on the necessary role of institutional investors. On the side of investors, the necessary conditions are large scale investment in equities and bonds, traded in liquid markets which allow value investors (whether householders or professional fund managers) to exercise choice on the basis of performance as reflected (and constructed) in financial accounting data. From the corporate side, managers 
must have the power to exercise choice over patterns of merger, acquisition and organizational restructuring in an attempt to meet shareholder requirements; and finally there must be the development of senior management compensation schemes and career hierarchies which reward managers who play the value game.

If we turn to macro flows under coupon pool capitalism, the basic flows are summarised in diagram one below which assumes the coupon pool has been constituted as regulator by large scale flows from households under appropriate conditions. The diagram has a left and right side which can be separately described.

On the left hand side of the diagram we have households and the coupon pool. In employment relations (where labour hours are exchanged for income), households transact directly with corporations but in savings/investment relations, households instead direct funds into a coupon pool. The relationship between households and the coupon pool can be thought of as a life cycle relation which typically begins at or just after household formation and then involves accumulation and liquidation after 20 or 30 years. The velocity of dealing can of course vary so that, if coupons are bought in one period and sold in other, the interval could be days or years. The value of coupons bought at time T1 depends on the size of the flow of household savings and on the coupon price. The return from the investment depends on the annual stream of interest and dividend payments, and the price of the coupons at time T2, when they are sold. Households may invest their savings directly in the coupon pool or use professionally managed funds which pool savings. The coupon pool is not the secondary market in issued ordinary shares or the secondary and primary markets together because it includes all coupon investment opportunities, including bonds, venture capital and securitised paper.

The right hand side of the diagram presents the various ways in which corporations and coupon pool can interact. Under the simplest kind of productionist system, corporations (like railway companies in 1840 s Britain) issue coupons to obtain funds which can be used for productive investment; and, subsequently, part of corporate surplus will be distributed as interest and dividends back through the coupon pool. Through new issues and ipos, this function continues, though new issues generally only boom when stock prices are high because ipos are usually a way of selling an existing company to the public. If corporations distribute part of their surplus to shareholders, corporations can also use their surpluses (or more commonly issue new coupons) to buy other companies by acquiring all the share capital; corporate surpluses can also be used to buy back or redeem existing coupons rather than issuing new coupons. Corporations can also deal, actively or passively, in the coupons of other companies or government. It should not be assumed that households own firms in all kinds of coupon pool capitalisms because firms can own other firms (as under productionist capitalism), albeit with different motives and dealing patterns.

From this diagrammatic point of view, financialisation acquires a new meaning as changes in the flows, rules and motives/incentives which facilitate new household and firm interactions that reinforce linkages and amplify effects. The changes here could include, for example:

- Financial incentives and/or modification of unfunded state or enterprise pension schemes which encourage or require households to make their own pension provision through funded schemes, thus increasing the flow and stock of funds. State earnings related schemes of the mainland European kind inhibit large scale flow into the domestic coupon pool.

- Liberalisation of the rules governing the kinds of coupon which institutions can hold. Thus, US and UK pension funds moved from bonds to ordinary shares 30 years ago and the UK government now wishes to encourage pension funds to invest in venture capital.

- A more active market for corporate control as patient shareholders espouse value or value investors become more important. MORIN 
(2000) argues this has happened in France with the break up of local networks and the arrival of US investors.

- Permissive legislation to allow new behaviours. National law has been changed to allow Dutch firms to buy back their own shares and German law will be changed to allow firms to sell cross shareholdings without incurring punitive capital gains liabilities.

When a concept like coupon pool capitalism is introduced, it is impossible to avoid the inevitable questions about whether and how the construct represents specific cases? At national level, the generic form exists only in the USA and UK: these are the only large countries in the world with a developed right hand side to the diagram and massive flows of long term savings from households to coupon pool which account for $10-15 \%$ of GDP. Elsewhere what we have is uneven left handed national developments, as in France, where MORIN (2000) argues much of the left hand is in place but pensions are not routed through the capital market. But this kind of listing of national cases can be misleading and understates effects because the coupon pool can generate action at a distance through global capital and product markets. Thus $35 \%$ of French shares are owned by foreigners, mainly the funds which represent American households (MORIN, 2000). And global product markets routinely bring firms from productionist countries into competition with financialised firms from the US or UK for whom financial results are primary.

More fundamentally, the whole point of a generic approach is that it is not identified with the specific behaviours and performance observed in a specific case such as the US in the decade of the 1990s. Instead it provides a framework within which differences can be identified and consequences can be explored. The schema could be used to analyse the US or France or indeed to analyse Germany or Brazil if the aim was to examine flows and explore not how but whether the coupon pool regulates household and corporate behaviour. Equally, coupon pool capitalism is not some kind of model which predicts outcomes. Instead, it provides a way of thinking about what needs to be investigated and specified. Consider, for example, what happens to household and corporate behaviour if equity prices rise,

- Households will enjoy a wealth effect, but the strength of that effect depends on size of holding and whether equity is held directly by households. In the US, for example, such effects would be relatively much stronger than in the UK where $80 \%$ of shares are held by funds.

- Corporations may be encouraged into speculative coupon dealing (because shares can painlessly augment earnings from operations), provided suitable coupons are available and capital gains tax allows firms to retain a large share of the proceeds. In Germany, for example, capital gains tax has been a disincentive.

- Households may contribute more discretionary funds to the coupon pool and there may also be associated changes in the velocity of dealing. But, these effects will be less strong, in a country like the UK where savings are primarily contractual through pensions schemes and such like.

The overall effects depend on the size of the coupon pool, the scale of flows, norms of behaviour and regulation which together determine what households and corporations can and must do.

Thus, coupon pool capitalism is a generic defined by large scale flows but compatible with a variety of rules, behaviours and performance outcomes. This mutability of rules and behaviour can be illustrated from the short history of coupon pool capitalism so far in the US and UK which shows substantial variation of capital market norms and corporate behaviour. As for norms, the US and UK capital markets have generally insisted on higher minimum returns on capital for all corporations regardless of sector; but in 1999-2000 they discovered digital technologies and were (for a while) eager to 
provide capital for .com firms without any profits. On behaviour, O'SULLIVAN (2000) emphasises that the proportion of corporate income distributed as dividends has risen in the US, but there is no such corresponding trend in the UK where the proportion of earnings distributed is no higher than in the 1960 s. Furthermore, the coupons do not have to be ordinary shares as they were in the 90 s because the coupon pool can outlive the cult of equity. If the real economy and equity values both turn down sharply, shares would lose their attraction and securitised bonds could be as big in the 2000s as junk bonds were in the USA in the 1980s.

The indeterminacy is increased because there are usually practical limits to what can be brought inside the accumulation circuit which (via the coupon pool in one national economy) connects households that invest and corporations which create surplus. Many households will be too poor to make significant long term savings and many economic activities cannot easily be reorganized on a corporate basis to yield returns which meet coupon holders requirements The US and UK examples of coupon pool capitalism in the 1990s demonstrate this point because both are " $40 \%$ economies" Only the fortunate forty percent, in the top two quintiles (Q4 and Q5) of households by income, make significant long term savings while poorer households do not in both the US and UK (FROUD, 2001). And in an economy like the US or UK, where $80 \%$ of the corporatised economy is quoted, only just over half the economy is corporatised with the rest accounted for by government and the personal sector (FROUD, 2000b) Despite Thatcher's privatisations in the 1980s, the size of the corporate sector in the UK has not increased. Many key relations and properties are therefore defined by the interaction between what is inside and outside the (mainly domestic) circuits which connects the fortunate $40 \%$ and corporate business.

Furthermore, the logics of financialisation will hardly abolish or effortlessly overcome the operation of other logics inside and outside any coupon pool capitalism for three reasons:
(1) Within any coupon pool capitalism where income from employment remains primary for most households, financialisation does not suspend macro and monetary effects arising from employment relations and the distribution of income through wages. In particular, in the neo liberal context of the US and the UK, financialisation does not suspend the important link between the composition of employment and composition of demand which we have analysed elsewhere (FROUD, 1997). The downspiral produced by a deterioration in wages and conditions for large groups in the population is unlikely to be countervailed by wealth effects. In this respect we disagree with BOYER (2000) whose simplified model of a wealth based growth regime turns orthodox Keynesian assumptions upside down when it argues the negative effects of wage cuts on aggregate demand could be more than counter balanced by wealth effects arising from increased profits and share price appreciation. While this outcome is possible in a wealth based growth regime where share ownership is universal, it is unlikely in most of the easily envisaged variants on the current forms of coupon pool capitalism.

(2) Any national coupon pool capitalism will for the foreseeable future operate in a partly non financialised world because in many countries, the basic institutional conditions are not met and financialisation cannot therefore easily augment flows and linkages. The Mannesman affair showed the growing power of value investors in Germany which will, of course, be reinforced when banks are allowed to unwind cross shareholdings without punitive capital gains But, as JUERGENS (2000) argues, bank based finance, codetermination and productionist management orientations continue to sustain the distinctive German corporate governance system. Many key outcomes for financialisation will therefore be determined by contest in global product markets between firms which are subject to 
different governance logics. In the Japanese case, MORGAN \& TAKAHASHI (20001) argues that none of the institutional conditions are in place and attributes current Japanese economic problems to the dysfunctional survival of circuits of accumulation (through which banks mobilised household savings for productive investment) into the 1980s when the corporate system was generating large surpluses. With Japanese ordinary shares currently at a 15 year low and the Japanese government at the limits of its borrowing power, it is hard to see how coupon pool capitalism can unjam the Japanese economy.

(3)Finally, financial logic may (like the economic in classical Marxism) be determinant in the last instance which never comes. A variety of institutions and non financial logics retain some power of resistance in a coupon pool system and, where the processes of financialisation are only beginning, the scope for assimilation, adoption and adaptation is considerable. These themes have been taken up by German researchers who are now documenting the assimilation of "shareholder value" into the German model. Thus, KADTLER \& SPERLING (2001) present case material from German auto companies which suggests that financialisation and globalisation challenge but do not undermine the local industrial sources of power which sustain collective bargaining at plant and company level. The one caution must be that Germany hardly represents a coupon pool capitalism and the observation of union influence is made in the later stages of an economic upswing. The German auto industry is a high breakeven industry which would be forced into loss by a sustained downturn which could represent the last instance for the local accommodations of the industry.

The addition of all these qualifications adds intellectual subtlety and real indeterminacy and raises a key question. Can a generic concept, like coupon pool capitalism work to produce a strong story line about dynamics and how is corporate and household behaviour is changed after financialisation. These questions are answered in the next section.

\section{Dynamics and Story Line: Coupon Pool in the UK or USA}

$\mathrm{T}$ he cases considered below are the US and UK, the two advanced capitalist countries where financialisation has created large scale flows and the coupon pool has been inaugurated as a regulatory institution for firms and households. Because the cases are complex, our analysis focuses on three sites (firms, households and the coupon pool) and at each site starts from some key empirics before identifying the key contradictions which drive the dynamics. Although behaviour and norms are mutable and the future is uncertain, the analysis does generate a story line which could be summed up as the opposite of regulationism. Since the end of the long boom, the regulationists have sought a new growth regime or a set of institutional conditions under which coherence could be restored to bring us 30 more glorious years of stable prosperity: thus, Boyer's question is whether widespread share ownership could inaugurate "a wealth based growth regime". Our contrarian story is about how the coupon pool intensifies contradictions and inaugurates incoherence at the level of firms and households at the same time as it increases instability: our observation is that coupon pool capitalism so far is a non system which moves on quickly after ending badly.

\subsection{Firms: a new competition and more moves}

In the US business press, financialisation manifests itself as a change in the mentality of US managers who now worry about pressures from the stock market not Japanese competitors. Back in the 80s (manufacturing) competition was represented in physical terms centred on product and process, with American consumers making Japanese firms like Toyota into winners. Now management focuses on financial results 
Table 2 - U. S. Corporate Return on Capital Employed

All US Corporations, Return on Capital Employed

\begin{tabular}{lccccc}
\hline & $\begin{array}{c}\text { Total capital } \\
\text { employed }\end{array}$ & $\begin{array}{c}\text { Total income } \\
\text { before interest } \\
\text { and tax* } \\
\text { \$bil. }\end{array}$ & $\begin{array}{c}\text { Total income } \\
\text { before interest } \\
\text { and after tax** }\end{array}$ & $\begin{array}{c}\text { ROCE } \\
\text { (before tax) }\end{array}$ & $\begin{array}{c}\text { ROCE } \\
\text { (after tax) }\end{array}$ \\
\hline 1985 & $\$$ \$bil. & 700 & $\mathbf{\%}$ & \% \\
1990 & 5,003 & 809 & 1,077 & 16.2 & 14.0 \\
1991 & 7,404 & 1,196 & 962 & 13.5 & 14.5 \\
1992 & 7,975 & 1,078 & 873 & 11.8 & 12.1 \\
1993 & 8,442 & 999 & 895 & 11.3 & 10.3 \\
1994 & 9,237 & 1,044 & 1,020 & 11.7 & 9.7 \\
1995 & 10,131 & 1,188 & 1,264 & 12.7 & 10.1 \\
1996 & 11,467 & 1,458 & 1,353 & 12.0 & 11.0 \\
\hline
\end{tabular}

Source: Statistical Abstract of the United States, US Census Bureau

Notes: *Excludes regulated investment companies

** Before tax credits

for the capital market in a world where American management can regain its leadership role and GE under Jack Welch is the model. US chief executives cannot publicly dissent from this new rhetoric though their conduct raises quite interesting questions about commitment and delivery because most of these CEOs are on stock option plans where the targets for share price increase and earnings growth are hardly aggressive.

The financial returns to management effort so far are mixed and disappointing. In the 1990s, the UK and US stock markets set two targets: first, all established corporations should get a return on capital of $12-15 \%$ after tax or more, a hurdle which represents their imputed cost of capital; second, share price should increase in line with the market. But, although share prices went up, most US and UK corporations struggled to raise return on capital despite an economic upturn: as Table 2 shows, the ROCE for all US corporations was stubbornly $11 \%$ or below. The paradox is that, although corporate America embraced value metrics such as Stern Sewart's
EVA, at a cyclical peak in the late 1990s three quarters of giant UK and US corporations did no more than just about meet the market's expectations with returns on capital within 2 or 3 percent of the hurdle (FROUD, 2000b).

If corporations underperform, the consultants' alibi is that value based management has not been properly implemented via stock options, incentive packages and the like. Our alternative and more plausible explanation is that there are structural limits on cost recovery and the rate of return in most activities (FROUD, 2000b). This explanation is certainly consonant with the observation that high return corporations in the UK typically operate in sectors like pharmaceuticals, software media and tobacco where they have special case advantages like intellectual property rights, brands and immateriality which cannot be generalised (FROUD, 2000a). In other sectors, the expectations of the stock market have done no more than establish a long term operating contradiction between what the capital market requires and what management can deliver in most activities from 
competitive product markets (even with the benefits of flexibilised labour markets).

The medium term resolution of this contradiction depends not on management effort but on whether and how the stock market changes its expectations, especially in response to a downturn when most corporations would spectacularly destroy value. One might suppose that it would be sensible for the market to recognise the limits of management against structural forces and to vary the hurdle rate by activity. But, a first experiment with capital market double standards has already ended in market crash and corporate bankruptcies. In the .com bubble, the capital market eagerly bought ipo stock in firms with digital prospects and no profits; and then chased these stocks to giddy heights before it all went wrong in Spring 2000 when US internet stocks crashed by $50 \%$ in one month (FROUD, 2000d). The (temporary) availability of free capital only encouraged some new economy companies like Amazon to adopt unsound business models with no cost recovery from operations so that these firms could only keep going as long as the capital market provided new finance (FROUD, 2000d).

In the old or new economy, the convention is now that the stock market leads and corporate management follows: so that every business model must adjust to the capital market's changing requirements. But, the contradictions between rhetoric and result are such that the stock market cannot systematically impose "discipline" on managements which fail to deliver value. If the stock market identifies an easy value increasing option, such as selling out to a hostile bidder or unbundling the businesses, then underperforming managements will be punished. But even here, the solution may not be straightforward. When British Telecom was burdened with debt after bidding for third generation licenses, in late 2000 the market pressured management into planning a break up by selling off mobile, directory and landline businesses; and then valued mobile companies so low that the break up of BT had to be postponed. Many underperforming manage- ments can hope to survive with lame promises of improvement and a judicious change of senior figureheads. Survival prospects are generally good where the market does not know what to do about the sector, as with Ford or GM in volume cars; or where the individual firm has hard to solve problems which deter takeover, as with Marks and Spencer in the UK.

But if corporate managements do not and cannot deliver the shareholder value they promise, they do change their behaviour in ways which shift the old boundaries of firm and industry and create a new competition. These important developments can be illustrated by considering the global auto business. Here GM, Ford and all the other big volume car corporations have failed to deliver adequate returns on capital largely because they operate in mature cyclical product markets, though an elite group including Ford and Toyota has matched the national share price index. Globalisation has aggravated problems because no volume company has been able to put together a portfolio of profitable positions in two of the major three regional markets: thus, Ford makes its money on US pickups and RVs with European operations only marginally profitable and Toyota makes three quarters of its profits from selling saloons in the US and very little from Japanese market leadership.

Against this background, the pressure for financial results encourages a focus on low and high return divisions and activities which, in turn, encourages divergent thinking about core activities. Generally, the fashion for vertically disintegrated firms is encouraged as firms occupy less of the supply chain and use power against those up stream and downstream. Old productionist definitions of an industry, as the group of firms producing competing products, are displaced. Firms instead start to think in terms of the sector matrix which includes all the competing and complementary goods and services necessary to a function like motoring or health care (FROUD, 1998). Thus, Ford signals that components can be bought in more 
profitably by spinning off its components business as Visteon; it also questions whether assembly is a core activity by experimenting with outsourced assembly in Brazil; and at the same time buys service businesses and builds finance businesses which promise more profit (FROUD, 2000e). At the same time, transforming moves are hard to find for a company like Ford which is making more than five million cars a year and is already strong in the most obvious related service business of car finance.

If individual companies cannot easily be reinvented, sectoral dynamics are often transformed. At sectoral level, the general result is a more anarchic competition of all against all with increasingly unpredictable results. Cross selling within the matrix leads to invasion of each other's markets with intensified competition generally reducing the margins which provide the motive for new entry. Thus, all the car companies, including specialists like BMW, are now trying to build up finance businesses of the kind which only Ford and GM have traditionally run. This brings the car companies into competition with all the old and new suppliers of personal finance from banks to supermarkets. Furthermore, in most global businesses, financialised corporations oriented to the capital market compete with productionist corporations oriented to product market and labour process achievements. Thus, the financialised Ford now competes with Renault which got into the big league by buying $37 \%$ of Nissan in a move which would not have been sanctioned by the US stock market. The results of such contests are especially unpredictable because we have no experience of coupon pool capitalism in recession and do not know whether and how the stock market would force US companies into retreat in a downturn. The gentle weakening of the US car market has already encouraged Ford and GM to cut back on their loss making European operations and build up cash reserves from which dividends could be maintained.

Within this context of an unpredictable new competition, the only safe prediction is that the gap between expectation and outcome will drive corporate management towards ever more restructuring in financialised economies where the flood of savings on to the market makes it easy to sell new securities. If Count Basie famously decided that the answer was to play fewer notes, management under coupon pool capitalism has a different aesthetic and favours ever more signals and moves. In British GEC, we identified 79 major restructuring events involving acquisition, divestment or joint venture between 1988 and 1998 (FROUD, 2000b). The restructurings included backing one third of the company into joint ventures so as to avoid takeover and ended in 1999 with the break up of the company whose defence equipment business was sold to BAE so that GEC's rump could become Marconi, an acquisitive minor telecom equipment manufacturer. Expect more merger and acquisition, divestments, rightsizing, outsourcing, buy outs and buy ins which incidentally make like for like performance comparisons very difficult. Also expect lots of financial engineering involving share buy backs, tax dodges, sale and leaseback, pension fund contribution holidays and such like which start from the cynical premise that the market is easily impressed by earnings.

"Shareholder value" is probably an unrealisable project for most corporate managements because gains made for capital at the expense of labour are given away through product market competition. But, in the absence of value, restructuring and financial engineering which promise temporary relief are quite good enough in a world where the managements of blue chips now resort to the cheap tricks which were the prerogative of dodgy conglomerates like Hanson in the 1980s.

\section{Households: Inequality and Risk}

$I^{t}$ new corporate norms and behaviours are the highly visible elements of coupon pool capitalism. the semi visible elements are the changes in household behaviour around new circuits of savings and investment. Political 
economists who assume that the behaviour of corporate managers does matter, need to be persuaded that the behaviour of individuals in households also matters. Coupon pool capitalism includes both insofar as they are influenced by the capital market and refocuses attention on the household, an important institution now mainly discussed by communitarians and the radical right. Coupon pool capitalism also highlights inequality, a desperately unfashionable issue in the UK where Third Way thinkers, like Giddens, prefer to talk about social exclusion. Our aim here is to re-establish the economic salience of inequality by highlighting how financialisation promotes circuits of accumulation which accelerate inequality in ways that increase the importance of the household.

Business authors like RAPPAPORT (1998) assert that we are all shareholders now, but the empirics tell a different story. As we have already noted, in the UK and USA, shareholding is the monopoly of the fortunate $40 \%$ in the top two quintiles (Q4 and Q5) of households by income. As Table 3 shows, this group accounts for $90 \%$ of all long term savings and investment in the US and $80 \%$ in the UK. Only these relatively affluent households can afford to forego current consumption, defer wages and put $10 \%$ of their income into shares through pensions, insurance and savings plans. The fortunate $40 \%$ can then realistically hope to build up a stockmarket fund which provides for a comfortable old age and retirement. The household savings circuit through the stock market directly accelerates the inequalities of old age and ensures that a majority of the population derives little benefit from any distribution of dividends or the rise of corporate share prices.

But the fortunate forty percent is not a homogeneous group. At the top end, it includes a small number of enriched managers, who benefit from high salaries and stock options or ipos which have been hugely rewarding in the long bull market of the 90s. The chief executives of US giant corporations are now routinely paid in millions per year: including unrealised share options, the CEO of Coca Cola earned $\$ 90$ million in 2000 (Guardian, 3 March 2001). Even in an unexciting UK blue chip like Shell, the chief executive earned 1.8 million pounds in pay and realised share options in 1999 and his deputy earned 820,000 . In the long bull market of the 1990s, share options for top managers acted as a mechanism which shifted some lucky managers out of the salariate. But, at the bottom end, the fortunate forty per cent includes many households of people like us. The average gross household income in quintile 4 in the UK was just 28,000 pounds and in the USA was just $\$ 48,000$ in 1996-7 (FROUD, 2001). The fortunate forty percent includes many public sector professionals in education, health and social services whose modest salaries have at best risen with the cost of living for the past twenty years.

The existence of an enriched group has emerging consequences for national identity, social cohesion and patterns of demand. For the time being, in a world of globalisation our stock markets are still, rather curiously, organised on a national basis: US financial institutions are diversifying slowly from a position where in the early 1990 s they held $94 \%$ of their stock market wealth in US stocks (WATSON, 1999) but UK funds are still overwhelmingly invested in UK stocks. Global reach has traditionally been provided by the corporate managers of quoted MNCs not by the pension fund managers who trade their shares. But, that is likely to change with mergers between national exchanges which are currently on the agenda. The managerially enriched can then become members of an increasingly rootless English speaking cosmopolitan elite with assets (and homes) in several countries, a large demand for personal services and little in common with the poorer citizens of any country. If gross inequalities of wealth and income become part of metropolitan capitalism, this is likely to encourage the further development of bipolar patterns of demand; with a proliferation of ill paid retail and personal service jobs that could be filled by locals or immigrants. All this could be represented as, the 
Table 3 - US and UK Distribution of Household Income and Savings

\begin{tabular}{|c|c|c|c|c|c|c|}
\hline \multicolumn{7}{|c|}{ US Distribution of Household Income and Savings (\$ p.a.) 1996/7 } \\
\hline & \multicolumn{5}{|c|}{ Quintile Group } & \multirow{2}{*}{$\begin{array}{c}\mathrm{Q} 4 \& \mathrm{Q} 5 \text { as } \\
\% \text { of total }\end{array}$} \\
\hline & 1 & 2 & 3 & 4 & 5 & \\
\hline Gross Income & 16,331 & 24,169 & 33,625 & 48,477 & 98,396 & 66.2 \\
\hline Disposable Income & 16,252 & 23,811 & 32,542 & 44,510 & 86,613 & 64.4 \\
\hline Savings and Investment & 371 & 1,122 & 2,604 & 6,552 & 30,917 & 90.1 \\
\hline $\begin{array}{l}\text { Savings and Investment as } \\
\% \text { of Disposable Income }\end{array}$ & 2.3 & 4.7 & 8.0 & 14.7 & 35.7 & \\
\hline \multicolumn{7}{|c|}{ UK Distribution of Household Income and Savings ( $£$ p.a.) 1996/7 } \\
\hline & \multicolumn{5}{|c|}{ Quintile Group } & $\begin{array}{l}\text { Q4 \& Q5 as } \\
\% \text { of total }\end{array}$ \\
\hline & 1 & 2 & 3 & 4 & 5 & \\
\hline Gross Income & 5,985 & 11,245 & 18,656 & 27,741 & 48,261 & 67.9 \\
\hline Disposable Income & 5,935 & 10,746 & 16,383 & 23,160 & 37,893 & 64.9 \\
\hline Savings and Investment & 144 & 487 & 1,197 & 2,420 & 5,172 & 80.6 \\
\hline $\begin{array}{l}\text { Savings and Investment as } \\
\% \text { of Disposable Income }\end{array}$ & 2.4 & 4.5 & 7.3 & 10.4 & 13.6 & \\
\hline
\end{tabular}

Sources: US - Consumer Expenditure Survey, Table 45, Bureau of Labor; UK - Family Spending 1996-7, Office for National Statistics (ONS).

Notes: Gross income is income before tax and includes wages and salaries, self-employment income, private and government retirement income, interest, dividends and other income and other income. Disposable income is income after taxes and benefits. Savings and investment includes investments in life and other personal insurance plus pensions contributions and other savings.

recreation of the third world in the first as part of a future whose social tone is more like Brazil than Nordic social democracy.

Although the managerially enriched are fascinating, for much the same reason as lottery winners, they will be few in number and much more depends on the prospects of the ordinary people on modest incomes in Quintile 4 households or those in lower income households in Quintile 3 and 2 households who have no realistic hope of security through the stockmarket. The household is an increasingly important institution for such individuals. We all live in households and, if we add other sources of income to wages and salaries, $84 \%$ of gross domestic product goes through households (FROUD, 2000c). The household has always been an active shaper of consumption and savings patterns and an influence on living standards: the household aggregates income; it raises living standards by saving expense when consumption is shared; and the household buffers hazards like unemployment and old age when savings are inadequate. In the advanced societies, the household has generally become more important with the dissolution of social settlements since the 1970s. Previously, full employment, trade unions and universal social security had established a system of floors and ceilings on competition which made individual independence (for men) much easier.

But, with financialisation, the household now becomes much more economically important for 
the majority whose individual incomes are modest, low or insecure.

(1) If long term savings provision has not been made, the household is the buffer institution and lender of last resort which may cover the down side risk of financialisation for the individual. The idea behind capital market based provision for individuals in old age is that each individual builds up his or her own fund. Under the old fashioned defined benefit schemes offered by public sector and blue chip corporate employers in the US and UK, the risk of fund underperformance after long years of contribution was borne by the employer who guaranteed a pension fixed in relation to final salary. But, the shift to defined contribution schemes (and to personal pensions in the UK), leaves the risk of underperformance with the individual whose pension depends entirely on what's in the individual fund. This kind of risk is intensified under a financialised system with the spread of products like the endowment mortgages widely sold in the UK.

(2) More positively, the surest way of getting into the higher income quintiles and achieving income levels which allow long term saving, is to pool the earnings of two moderate wage earners in the one household. This has become increasingly practicable as female work force participation rates have risen towards $75 \%$. In the US or UK, the most telling statistic is the average number of wage earners per household in different quintiles: in the UK in 1995-6 this rises from 0.6 and 1.1 wage earners in Quintiles 2 and 3 to 1.6 and 2.1 wage earners in Quintiles 4 and 5. Broadly speaking, in both countries the fortunate $40 \%$ are those who live in two income households.

The most visible institutions of coupon pool capitalism are the capital market and the corporation which collectively require and produce value. Arguably, more important for a majority of the population, is the household which buffers the consequences of the absence of value for the individual. This is, of course, a $21^{\text {st }}$ century reinvention of the role which the household played in the $19^{\text {th }}$ century before the invention of modern social security. And we can only expect that the household will do this job very badly in a $21^{\text {st }}$ century society where family relations are becoming increasingly contingent and serial as life expectancy increases. One in three English marriages ends in divorce which, after recent changes, now individualises provision through pension splitting; while bereavement leaves many old people living in single person households which can expect little family assistance.

The response of the Blair and Clinton administrations to inadequate provision for old age was to envisage putting more of our future into long term provision through the stock market (FROUD, 2001). This ignores the actuarial realities that a competence in old age for modest savers requires long years of contribution and very favourable assumptions about continuing high returns and does not consider the macro consequences of routing more and more money into the stock market. However, it may seem to have some rationale in terms of diversifying risk. A British style "pay as you go" unfunded state pension system uses a tax system which bears on returns to labour either through income or consumption taxes which are mainly paid out of wages and salaries. Would it not be more sensible to tap the returns on capital as well though shares and bonds through funds which, in principle, could be collective instead of individual? To understand why this solution promises more than it can deliver, it is necessary to analyse returns to capital.

\section{Coupon Pool: a Giant Ponzi Scheme?}

$\mathrm{E}$ vents of the past decade have highlighted the link between the coupon pool and macro trajectory and stability. After an asset and stock price bubble had burst, the Japanese economy lapsed into chronic depression for much of the 90s, while the American stock market and real 
economy jointly sustained a decade long upturn. In 1998 the hedge fund crisis, following on from the Asian crisis, brought world capitalism to the brink. A couple of years later, 2000 was the year of the "new economy" which coupled a bubble in .com stocks and equally short lived American productivity miracle and. The tech stock crash of Spring 2000 triggered a chain of events which (despite interest rate cuts by the Fed) provoked an inventory correction that may yet turn into a major US recession with implications for the rest of the world. The issue of the stockmarket in a putative "wealth based growth regime" has been explored by BOYER (2000) through macro economic modelling (of a closed economy) which generates interesting conclusions about the risks of asset price bubbles and the danger of real balance effects. Here we provide an alternative coupon pool view of the role of the stock market in US capitalism where the immediate question is whether and why the market is (still) grossly overvalued?

If we consider US share prices, the key empirical observation is that, although corporate management found it difficult to deliver increased earnings, share prices rose unsteadily by $10-20 \%$ per annum each year through the 1990s. In consequence, $80 \%$ of shareholder gains over the decade came from higher stock prices not distributed earnings and the sustainability of prices became an increasing issue. As Table 4 shows, stock valuations have fluctuated widely over the past 70 years. The median P/E ratio for S and P 500 stocks is 15:1 over the past 75 years and this span includes periods like the late 70s and early 80s when the S and P 500 was trading at or below 10:1. The long bull market took the S and P 500 to a peak P/E ratio of more than 30:1, subsequently corrected to some $26: 1$ by March 2000 when the market was still falling. Some technicians then argued that the gap between bond and ordinary share yields justified this valuation; most believed that, in a slowing US economy, existing market valuations could not be justified on any reasonable expectation of earnings or continued share price growth. By
Spring 2001, deepening gloom was fed by continued heavy falls in the tech stocks quoted on the Nasdaq which was $60 \%$ down on its 2000 peak when the main NYSE market was only $20 \%$ down. In the .com bubble, the market bid up the price of tech stocks so that "info tech" stocks were trading at a median p/e ratio of 150:1 at their peak in early 2000.

SHILLER (2000, p. 203) attributes an overvalued market to collective psychology and "the combined effects of indifferent thinking by millions of people". The psychological element did play a major role in the.com bubble. This was about a dream of riches from new digital companies which was sold to the public by the US business media and turned into temporarily self fulfilling prophecy by the hucksters of Wall Street who generally compete to do the same thing. But, if we consider the decade long bull market (rather than the bubble), structural factors are more important. With $40 \%$ of the population making long term savings through the stock market, household pension and life insurance contributions account for a large and growing flow in the US and UK. In the USA, these household savings have increased from less than $10 \%$ of GDP to more than $13 \%$ of GDP, an amount which by the mid 1990s was 50\% larger than corporate capital expenditure. The structural explanation of the bull market is simply that, with financialisation, stock prices are driven by the pressure of middle class savings bidding for a limited supply of securities. The disconnect from (expectations of) earnings and growth then encourages a volatile investor psychology with irrational exuberance alternating with unreasoning despair through corrections whose timing and form are difficult to predict and complicated by policy response.

Some simple arithmetic can give us a broader view of these structural instabilities. Earlier forms of capitalism were defined by the contradictions around the extraction of surplus from labour; the current US and UK form is partly defined by the contradictions around the deposit of savings by households. The US and 
UK have realised a type of capitalism where, for the first time in history, depositing capitalists outnumber surplus creating workers. If we define the capitalist classes in the UK and US as those with significant savings and ownership claims, this includes all the individuals in Quintiles 4 and 5 and this group is 3 or 4 times larger than the global workforce of the large corporations quoted on their national exchanges. In the US, Quintile 4 and 5 includes some 120 million individuals whereas the global workforce of the giant corporations in the S and P 500 totals no more than 34 million. This basic arithmetic guarantees a displacement from shareholder value through increased earnings to shareholder value through higher share prices as the middle classes validate their expectations of comfortable retirement by bidding up the price of shares in the US and UK forms of coupon pool capitalism.

Such household behaviour both delivers and frustrates security because it creates a stock market which operates like a giant Ponzi scheme. Ponzi was the US fraudster who sold promissory notes that offered $\$ 15$ for very $\$ 10$ deposited after 90 days, banked the money and then used new deposits to pay off his obligations. The current US or UK stock market shares several characteristics with Ponzi's scheme: first, there is a limited connection to any activity base of corporate trading for profit because most of the gains do not come from this source; second, the deposits of late comers provide the basis for repaying early savers, through fraud in Ponzi's scheme and through waves of appreciating share prices in the case of the current US stock market. The real effects of the inevitably resulting share price instability are uncertain when the wealth effects on current household consumption vary according to whether shares are directly held by households who sense gain or losses on their portfolio. This is primarily an issue in the USA where, as recently as 1990, households directly held $50 \%$ of shares. The most obvious household response to temporary or sustained underperformance of share prices in the US would be to consume less and save more which is likely to aggravate any economic down turn and, in the longer term, intensify the instability of share prices.

More generally, there can be little doubt that the US and UK types of coupon pool capitalism are inherently more unstable than a stereotyped "Fordism". If a Fordist regime has to relate labour and product markets, the US or UK types of coupon pool capitalism have to balance labour, product and capital markets when operating and patrimonial contradictions frustrate stability. The operating contradiction is that (even with flexibilised labour markets) the persistence of oversupplied and competitive product markets with cost recovery problems frustrates the creation of shareholder value through earnings. The patrimonial contradiction is that shareholder value is then created unstably through the flow of middle class savings onto the market which feeds rising stock prices and corrections. In the US and UK form, widespread share ownership turns out to be a risky habit which, like smoking in bed, combines comfort with the risk of immolation.

\section{References}

BOYER, R.: "Is a finance-led growth regime a viable alternative to Fordism? A preliminary analysis", Economy and Society, v.29, n.1, p.111-45, February, 2000.

DORE, R.: Stock Market Capitalism: Welfare Capitalism. Oxford: Oxford University Press, 2000.
FROUD, J.; HASLAM, C.; JOHAL, S.; WILLIAMS, J. \& WILLIAMS, K.: "From social settlement to household lottery", Economy and Society, v.26, n.3, p.340-72, August, 1997.

FROUD, J.; HASLAM, C.; JOHAL, S. \& WILLIAMS, K.: "Breaking the chains? a sector matrix for motoring", Competition and Change, v.3, p.293-334, 1998. 
FROUD, J.; HASLAM, C.; JOHAL, S. \& WILLIAMS, K.: "Shareholder value and financialization: consultancy promises, management moves", Economy and Society, v.29, n.1, p.80-110, February, 2000a.

FROUD, J.; HASLAM, C.; JOHAL, S. \& WILLIAMS, K.: "Restructuring for shareholder value and its implications for labour", Cambridge Journal of Economics, v.24, n.6, p.771-797, November, 2000b.

FROUD, J.; HASLAM, C.; JOHAL， S. \& WILLIAMS, K.: "Representing the household: in and after national income accounting", Accounting, Auditing and Accountability Journal, v.13, n. 4, p.535-60, 2000c.

FROUD, J.; HASLAM, C.; JOHAL, S. \& WILLIAMS, K.: "A new business model?" (mimeo of paper prepared for New Economy Workshop, London 8-9 ${ }^{\text {th }}$ December 2000), 2000d.

FROUD, J.; HASLAM, C.; JOHAL, S. \& WILLIAMS, K.: "Ford's new strategy" (mimeo), 2000e.

FROUD, J.; HASLAM, C.; JOHAL, S. \& WILLIAMS, K.: “Accumulation under conditions of inequality", Review of International Political Economy (forthcoming), 2001.
JUERGENS, U.; NAUMANN, K. \& RUPP, J.: "Shareholder value in an adverse environment" Economy and Society, v.29, n.1, p.54-79, February, 2000.

KADTLER, J. \& SPERLING, H.J.: "After globalisation and Financialisation: logics of barganing in the German auto industry", Competition and Change (forthcoming), 2001.

MORGAN, G. \& TAKAHASHI, Y.: "Shareholder value in the Japanese context", mimeo, 2001.

MORIN, F.: "A transformation in the French model of shareholding and management", Economy and Society, v.29, n.1, p.36-53, February, 2000.

O'SULLIVAN, M.: Contests for Corporate Control. Oxford University Press: Oxford, 2000.

RAPPAPORT, A.: Creating Shareholder Value. Free Press: New York, 1998.

SHILLER, R.J.: Irrational Exuberance. Princeton NJ: Princeton University Press, 2000.

WATSON, M.: "Rethinking capital mobility, reregulating financial markets", New Political Economy, v.4, n.1, p.55-75, 1999.

WILLIAMS, K.: "From shareholder value to present day capitalism", Economy and Society, v.29, n.1, p.1-12, February, 2000.

\section{FINANCEIRIZAÇÃO E A APOSTA EM DIVIDENDOS}

\section{Resumo}

$O$ artigo descreve as mudanças recentes nas formas de funcionamento do capitalismo contemporâneo baseada no papel autônomo alcançado pela esfera financeira. Discutindo com várias propostas de explicação do fenômeno, ele propõe uma explicação que acentua o caráter ao mesmo tempo paradoxal, contingente e contraditório do processo que estamos vivendo. A forma atual é originária dos países anglo-saxões e se espraia rumo aos demais países desenvolvidos e em desenvolvimento. Nos Estados Unidos e Inglaterra chegou-se a situação, para muitos pouco esperada, em que a quantidade de famílias detentoras de patrimônio acionário relevante ultrapassa o número de trabalhadores diretamente engajados nas empresas que estão cotadas nos mercados, dando centralidade ao mercado financeiro na criação e distribuição de riquezas daquelas sociedades. Entretanto, os autores argumentam que esse processo está baseado em hipóteses dificilmente realizáveis relativamente à capacidade das empresas fornecerem no longo prazo o volume de dividendos necessário para satisfazerem as expectativas e necessidades dos investidores.

Palavras-chave: tipos de capitalismo, governança corporativa, financeirização, formas de riqueza, tipos de renda, revolução dos acionistas. 